\title{
Tingkat penggunaan CT-scan untukpemeriksaan ameloblastoma di RS Wahidin Sudirohusodo lebih tinggi dibandingkan dengan radiografi konvensional Level of using CT-scan in examinating ameloblastoma at Wahidin Sudirohusodo Hospital was higher than conventional radiographies
}

\author{
Syamsiar Toppo \\ Bagian Radiologi \\ Fakultas Kedokteran Gigi Universitas Hasanuddin \\ Makassar, Indonesia
}

\begin{abstract}
Radiographies are commonly used in dentistry. One of them is CT-scan. CT-scan is used in a variety of cases, particularly in the oral cavity to detect the presence of ameloblastoma. This study aimed to determine the prevalence of using CT-scan at Wahidin Sudirohusodo Hospital to examinate ameloblastoma descriptive observationally using cross sectional study. This research is the base study by collecting data of the patients took $x$-ray, from the patients' dental record at the Installation of Medical Records in 2012. Then, the results are distributed into tables and presented by graphic. Data showed that ameloblastoma patients examinated with CT-scan are 55 patients (83.3\%) and other conventional $x$-ray are 11 patients (16.7\%) of the total 66 patients. It was concluded that the level of using CT-scan for examination of ameloblastoma in the Hospital was higher than other conventional radiographies.
\end{abstract}

Key words: radiography, CT-scan, ameloblastoma

\begin{abstract}
ABSTRAK
Radiografi merupakan gambaran yang biasa digunakan dalam bidang kedokteran gigi. Salah satu jenisnya adalah CTscan. Pemeriksaan CT-scan digunakan pada berbagai kasus, khususnya pada rongga mulut untuk mendeteksi adanya ameloblastoma. Penelitian ini bertujuan untuk mengetahui prevalensi penggunaan CT-scan pada pemeriksaan ameloblastoma di RS Wahidin Sudirohusodo secara observational deskriptif dengan rancangan cross sectional study. Penelitian ini merupakan penelitian dasar dengan cara merekap data dari kartu status pasien foto ronsen, di bagian Instalasi Rekam Medik pada tahun 2012. Hasilnya kemudian didistribusi ke dalam tabel dan grafik. Data menunjukkan penderita ameloblastoma yang diperiksa menggunakan CT-scan sebanyak 55 pasien $(83,3 \%)$ dan alat konvensional lainnya 11 pasien (16,7\%) dari total 66 pasien (100\%). Disimpulkan bahwa penggunaan CT-scan untuk pemeriksaan ameloblastoma di Rumah Sakit tersebut lebih tinggi dibandingkan dengan radiografi konvensional lainnya.
\end{abstract}

Kata kunci: radiografi, CT-scan, ameloblastoma

Koresponden: Syamsiar Toppo, Bagian Radiologi Oral, Fakultas Kedokteran Gigi Universitas Hasanuddin. Jl.Kandea No.5, Makassar, Indonesia. E-mail: syamsiartoppo@yahoo.com

\section{PENDAHULUAN}

Radiologi merupakan cabang ilmu kedokteran yang berhubungan dengan pencitraan medis yang menggunakan mesin sinar- $X$ dan perangkat radiasi. Penggunaan sinar ronsen telah lama dikenal sebagai suatu alat bantu dalam bidang kedokteran.Gambaran yang dihasilkan foto ronsen sangat penting terutama dalam mendeteksi adanya kelainan-kelainan yang tidak tampak menjadi dapat diketahui secara jelas, sehingga sangat membantu penegakkan diagnosis dan rencana perawatan gigi. ${ }^{1}$

Penggunaan peralatan berbasis teknologi sekarang ini, terutama pada foto ronsen, mengalami peningkatan; salah satunya perkembangan sistem komputerisasi untuk pengambilan gambar computed tomography (CT). Dalam bidang kedokteran gigi, radiografi yang biasa digunakan yaitu gambaran radiografi konvensional 2 dimensi (2D). Walaupun sudah ditingkatkan ketajamannya,namun teknik CT
3 dimensi (3D) sangat membantu untuk mengetahui luas kelainan struktur yang terlibat dan gambaran lebih akurat dibanding alat konvensional 2D. CTscan merupakan proses penggunaan sinar-X untuk memperoleh gambaran 3D dari ribuan gambar sinar$X$ 2D dengan menggunakan komputer untuk memperoleh gambaran 3D. CT-scan menghasilkan gambar-gambar yang sangat akurat dari objek-objek di dalam tubuh seperti tulang, organ, dan pembuluh darah.Hasil pencitraan yang dihasilkan CT-scan jauh lebih detail dibandingkan dengan hasil pencitraan yang diperoleh dari radiografi konvensional. CTscan dapat menghasilkan gambaran yang sangat akurat dari objek-objek di dalam tubuh, termasuk rongga mulut. ${ }^{2}$

Prinsip dasar CT-scan mirip dengan perangkat radiografi yang lebih umum dikenal.Kedua perangkat ini sama-sama bermanfaat intensitas radiasi terusan setelah melewati suatu objek untuk membentuk citra 
atau gambar. CT-scan dapat difokuskan pada satu organ atau objek saja. CT-scan sering digunakan dalam berbagai kasus dan kelainan dari beberapa jaringan maupun organ tubuh. ${ }^{3}$ Alat sinar-X 3D yang biasa digunakan adalah CT-scan medis dan cone beam CT-scan yang mampu menggambarkan jaringan lunak dan keras pada daerah maksilofasial. Penggunaan kedua alat ini di dalam kedokteran gigi sangat tinggi. Penggunaan CT-scan yang biasa dalamkedokteran gigi pada rongga mulut digunakan untuk mendeteksi kelanan-kelainan dari berbagai sudut kecil dari tulang kranium. ${ }^{4}$

CT-scan merupakan alat penunjang diagnosis yang mempunyai aplikasiuniversal untuk memeriksa seluruh bagian tubuh. CT-scan sering digunakan untukberbagai kasus,salah satunyauntukmendeteksi ameloblastoma di rongga mulut. ${ }^{5}$ Ameloblastoma adalah tumor odontogenik yang berasal dari epitel enamel organ atau ameloblas yang merupakan sel pembentuk gigi, berlangsung lambat, local invasive, dan sebagian besar bersifat jinak. ${ }^{6,7}$

Berdasarkan paparan mengenai perkembangan radiografi, yaitu CT-scan sebagai terobosan baru yang marak diperbincangkan sehubungan dengan pentingnya tingkat keakuratan dan keberhasilan penggunaanCT-scan, olehkarenaitu pada penelitian akan dibahas mengenai penggunaan CT-scan dalam membantu pemeriksaan pada ameloblastoma rongga mulut di Rumah Sakit Wahidin Sudirohusodo.

\section{BAHAN DAN METODE}

Penelitian ini bersifat observasional deskriptif menggunakan rancangan penelitian cross sectional study. Penelitian ini dilaksanakan di RS Wahidin Sudirohusodo pada tanggal 1-8 Maret 2013. Data diperoleh dengan cara mengumpulkan data yang diperoleh berdasarkankartu status di Bagian Instalasi Rekam Medik mengenai prevalensi CT-Scan pada pemeriksaan ameloblastoma, lalu dibandingkan dengan pemeriksaan yang menggunakan teknik radiografi konvensional, meliputi panoramik dan periapikal.

\section{HASIL}

Dari hasil penelitian ini, diperoleh data cara pemeriksaan ameloblastoma menggunakan CT-scan dibandingkan dengan alat konvensional lain (Tabel $1)$.

Dari tabel tersebut, terlihat bahwa penderita ameloblastoma diperiksa menggunakan radiografi sebagai pemeriksaan penunjang di RS Wahidin Sudirohusodo. Dari 66 penderita yang melakukan pemeriksaan ameloblastoma, terdapat 55 orang $(83,3 \%)$ yang menggunakan CT-scan dan 11 orang $(16,7 \%)$ yangmenggunakan radiografi konvensional lainnya. Dari data tersebut,jelas bahwa penggunaan CT-scan lebih tinggi dibandingkan alat konvensional lainnya sebagai pemeriksaan penunjang, dengan perbandingan 5:1.

\section{PEMBAHASAN}

Berdasarkan hasil penelitian mengenai prevalensi penggunaan radiografi CT-scan untuk memeriksa ameloblastoma di RS Wahidin Sudirohusodo dibandingkan dengan radiografi konvensional lain, diketahui bahwa penggunaan CT-scan masih lebih tinggi dibandingkan dengan alat konvensional lain sebagai alat pemeriksaan penunjang terhadap ameloblastoma.Data penelitian yang diperoleh oleh peneliti ini serupa dengan hasil penelitian yang didapatkan oleh Hasan,dkk yang mendapatkan hasil bahwa dari 30 orang pasien yang diteliti, diperoleh hasil 17 orang pasien diperiksa menggunakan CTscan dan 13 orang diperiksa menggunakan radiografi konvensional lainnya. ${ }^{9}$

Dari hasil perbandingan tersebut, disimpulkan bahwa tenaga medis di Makassar atau khususnya RS Wahidin Sudirohusodo sebagai salah satu rumah sakit yang memiliki fasilitas terlengkap di Makassar, telah memiliki pemahaman akan ketepatan dan keunggulan CT-scan dalam pemeriksaan perluasan ameloblastoma yang menjadi pilihan utama dan terbanyak dalam melakukan pemeriksaan dan diagnosis ameloblastoma.

Pencitraan yang menggunakan CT-scan dapat membantu untuk melihat kelainan-kelainan yang terjadi pada rongga mulut terutama massa tumor. Kondisi ini semakin menunjukkan bahwa sering terjadi ameloblastoma yang disebabkan oleh kelenjar saliva sehingga semakin memperkuat pentingnya penggunaan CT-scan untuk pemeriksaan penunjang standar yang adekuat untuk menegakkan diagnosis

Tabel 1 Prevalensi penggunaan CT-Scan dan alat konvensional lainnya pada pemeriksaan ameloblastoma di RS Wahidin Sudirohusodo pada tahun 2013

\begin{tabular}{ccc}
\hline Jenis alat radiografi & Frekuensi (n) & Persentase (\%) \\
\hline CT-scan & 55 & 83,3 \\
Alat konvensional lain & 11 & 16,7 \\
\hline Total & 66 & 100
\end{tabular}


ameloblastoma. Untuk melihat perluasan tumor dapat dilihat dari tingkat keberhasilan dan kualitas dari hasil gambar CT-scan tersebut.

Gambaran dari CT-scan merupakan gambaran digital yang direkonstruksi oleh komputer, yang secara sistematis memanipulasi data transmisi yang diperoleh dari proyeksi multipel. CT-scan juga akan menghasilkan gambaran yang lebih terinci dibandingkan radiografi konvensional lain, karena resolusi kontras yang sangat tinggi dari CT-scan. Salah satu alasan untuk menggunakan CT-scan ialah untuk memeriksa dan mengetahui perluasan ameloblastoma.
Dari hasil dan pembahasan penelitian ini, disimpulkan bahwa tingkat penggunaan CT-scan untuk menegakkan diagnosis ameloblastoma di RS Wahidin Sudirohusodo lebih tinggi dibandingkan dengan radiografi konvensional. CT-Scan sangat diperlukan dalam bidang kedokteran gigi baik untuk mendiagnosismaupun untukmendapatkan gambaran radiografi yang lebih rinci. Mengingat tingginya penggunaan CT-scan sebagai alat pemeriksaan penunjang, patut disarankan agar pihak rumah sakit lebih memperhatikan lagi peningkatan mutu sarana dan prasarana di bidang radiologi termasuk alat CT-Scan.

\section{DAFTAR PUSTAKA}

1. Yunus B, Murtala B. Pemanfaatan houmdfieldunit pada CT-scan dalam menentukan kepadatan tulang rahang untuk pemasangan implant. J Dentofasial 2010; 9(1): 34-8.

2. Rahmayanti L, Kurnikasari E, Rikmasari R. Analisis posisi kondilus menggunakan radiografi cone beam computed tomografi tiga dimensi pada kasus disc displacement with reduction. Dentika Dent J 2010:15 (2):115-9.

3. Syafriadi M. Tumor neoplasma dan non neoplastik rongga mulut. Yogyakarta: C.V Andi Offset; 2008. hal. 31-76.

4. Ekayuda I. Radiologi dignostik. Jakarta: FKUI; 2010. hal. 1-5

5. Patel PR. Lecture notes radiology. Jakarta: Erlangga; 2007. p. 2-9.

6. Paster FA. Pocket atlas of dental radiology. New York: Thime Stuttgart; 2007. p. 227-89

7. Tetradis S. Extraoral radiographic examination. In: White SC, Pharoah MJ. Oral radiology principle and interpretation. $5^{\text {th }}$ Ed. St. Louis: Mosby. Inc; 2004. p. 418-81.

8. Regezy JA, Sciubba JJ, Jordan. Oral pathology. St. Louis: Mosby; 2003.

9. Hasan YC, Prihartiningsih, Rahardjo. Ekspresi pada ameloblastoma. J Kedokteran Gigi 2010; 1:7-12. 